\title{
Phenotypic and Molecular Screening of Laccase-producing Bacteria Isolated from Automobile Workshop Soil Samples in Ado-Ekiti
}

\author{
Temitayo Omotunde Olowomofe ${ }^{1}$, Olaoluwa Jacob Oluyege ${ }^{1}$, Paul Ikechukwu Orjiakor ${ }^{1}$, \\ Ayodele Oluwayemisi Ogunlade ${ }^{2}$, Solomon Temitayo Olaoye ${ }^{1}$ \\ ${ }^{1}$ Department of Microbiology, Faculty of Science, Ekiti State University, Ado-Ekiti, Nigeria \\ ${ }^{2}$ Department of Food Technology, Federal Polytechnic, Ado-Ekiti, Nigeria
}

Email address:

motunde21@yahoo.com (T. O. Olowomofe), temitayo.olowomofe@eksu.edu.ng (T. O. Olowomofe)

\section{To cite this article:}

Temitayo Omotunde Olowomofe, Olaoluwa Jacob Oluyege, Paul Ikechukwu Orjiakor, Ayodele Oluwayemisi Ogunlade, Solomon Temitayo Olaoye. Phenotypic and Molecular Screening of Laccase-producing Bacteria Isolated from Automobile Workshop Soil Samples in Ado-Ekiti. International Journal of Microbiology and Biotechnology. Vol. 5, No. 3, 2020, pp. 97-102. doi: 10.11648/j.ijmb.20200503.14

Received: April 21, 2020; Accepted: May 13, 2020; Published: June 20, 2020

\begin{abstract}
This work was carried out to isolate hydrocarbon-degrading bacteria from oil contaminated soil sample in AdoEkiti and screen them for laccase production. Soil samples were collected and analyzed using standard microbiological techniques. The isolates were initially screened for hydrocarbon degrading ability on minimal salt medium supplemented with $1 \%$ crude oil and incubated for 14days. The isolates were further screened for their ability to produce laccase enzyme using plate screening and molecular techniques. Four of the isolates that gave the best results on tannic-agar plates were selected for PCR amplification of laccase gene using specific primers. The isolates were identified as Lactobacillus sakei, Pseudomonas aeruginosa, Bacillus cereus and Gracilibacter thermotolerans based on 16SrRNA sequencing. The DNA of these bacteria amplified the primer specific for laccase gene with $1300 \mathrm{bp}, 1400 \mathrm{bp}, 1600 \mathrm{bp}$ and $350 \mathrm{bp}$ respectively. For bioremediation to be effective, microorganisms must enzymatically attack the pollutants and convert them to harmless products. Therefore, laccase production potentials in these bacteria make them useful in bioremediation as laccase is known to break heavy phenol containing hydrocarbons. Further work can be done to determine the activity of this enzyme during the degradation of crude oil.
\end{abstract}

Keywords: Bioremediation, Laccase, PCR Amplification, Hydrocarbon-degrading Bacteria

\section{Introduction}

One of the major environmental problems faced by the world today is the contamination of soil, water, and air by toxic chemicals. Organic and inorganic pollutants from industries and extensive use of pesticides in agriculture have immensely contributed to this problem. Many of these compounds, such as polycyclic aromatic hydrocarbons (PAH), pentachlorophenols (PCP), polychlorinated biphenyls (PCB), 1,1,1-trichloro-2,2-bis(4-chlorophenyl) ethane (DDT), benzene, toluene, ethylbenzene, and xylene (BTEX) as well as trinitrotoluene (TNT), are persistent in the environment and are known to have carcinogenic and/or mutagenic effects $[1,2]$. Bioremediation has been the best option for converting these hazardous pollutants into less hazardous compounds by utilizing microorganisms. Hydrocarbon-degrading microorganisms are widely distributed in the soils, where they play important role in remediating polluted soils. When they come into contact with complex organic materials, extracellular enzymes are released to convert high molecular weight materials into diffusible fractions, which could be transported through the cell wall for assimilation. The role of enzymes in keeping the environment clean is immense; being implemented in the biodegradation of various environmental pollutants and biocatalyzing various reactions by substituting the environmentally hazardous and toxic chemical catalysts offering an environment friendly alternative [3]. Laccases (benzenediol: oxygen oxidoreductases; EC 1.10.3.2) are copper-containing enzymes that belong to the so-called blue copper oxidases. These enzymes are responsible for the oxidation of a variety of phenolic compounds as well as aromatic amines with the reduction of molecular oxygen to water [4]. In addition, in the presence of small molecular- 
weight compounds named redox mediators, laccases are able to oxidize non-phenolic structures [5]. This together with the fact that they only use molecular oxygen as a co-substrate instead of hydrogen peroxides as used by peroxides, make laccases very attractive for different biotechnological applications [6]. Laccases are also useful for the decompositon of azo dyes by oxidative methods [7].

Laccase and laccase-producing microorganisms play an important role in bioremediation of aromatic substances from contaminated soils, industrial pollutants and xenobiotics. They are able to oxidize toxic organic pollutants, such as polycyclic aromatic hydrocarbons and chlorophenols [8]. The ability of laccase producing microorganisms or purified laccases to eliminate a wide range of pollutants is currently one of the most interesting subjects for researchers in environmental biotechnology [9]. Screening of laccaseproducing microorganisms is paramount for selecting suitable laccase producing organisms. Screening of microorganisms for enzyme production is usually done by qualitative and quantitative assays which are accompanied with some imprecisions. Hence, molecular screening presents a rapid and more sensitive procedure for determining the enzymatic competence of microorganisms. In this study, hydrocarbon-degrading bacteria were screened for laccase enzyme using plate screening and molecular methods.

\section{Materials and Methods}

\subsection{Collection of Samples}

Soil samples were collected in sterile polythene bags at a depth of $10 \mathrm{~cm}$ from eight different mechanic workshops in Ado-Ekiti. Collected samples were transported to the laboratory for analyses.

\subsection{Isolation of Hydrocarbon-utilizing Bacteria}

One gram of each sample was introduced into sterile mineral salt medium $\left[\mathrm{NaCl}(0.1 \mathrm{~g} / \mathrm{l}) ; \mathrm{MgSO}_{4} \cdot 7 \mathrm{H}_{2} \mathrm{O}(1.2 \mathrm{~g} / \mathrm{l})\right.$, $\mathrm{KH}_{2} \mathrm{PO}_{4}(1.2 \mathrm{~g} / \mathrm{l}), \mathrm{FeSO}_{4} .7 \mathrm{H}_{2} \mathrm{O}(6.04 \mathrm{~g} / \mathrm{l})$ distilled water at $\mathrm{pH}$ 7.2] supplemented with $1 \%$ bonny light crude oil. The set up was incubated at $37^{\circ} \mathrm{C}$ for 7 days. After 7 days, $1 \mathrm{ml}$ of each set up was inoculated into a freshly prepared MSM with $1 \%$ of crude oil and incubated at $37^{\circ} \mathrm{C}$ for another 7 days. After 14 days, ten-fold serial dilution was carried out. Dilutions $10^{5}$ and $10^{6}$ were plated using pour plate technique. Plates were incubated at $37^{\circ} \mathrm{C}$ for 24 hours. Total hydrocarbon-degrading bacteria in the samples were calculated in colony forming units/ml (CFU/ml). Pure cultures were obtained using streak method and stored on agar slants as stock cultures for further analyses.

\subsection{Laccase Enzyme Screening}

The bacteria isolated were screened for laccase enzyme using tannic acid as a substrate. the isolates were inoculated in Nutrient agar plates containing 5\% tannic acid using agar diffusion method $[10,11]$. The plates were incubated at room temperature for $24 \mathrm{~h}$. Brown-black zones were observed at the center of some plates and the diameter of the zones was measured. Isolates with positive reaction were selected for molecular screening.

\subsection{Quantitative Assay of Laccase}

Laccase activity was measured using $2 \mathrm{mM}$ ABTS $\{2$, 2azino-bis (3-ethylbenzthiazoline-6-sulfonic acid) $\}$ as a substrate [12]. The reaction mixture consists of $10 \mathrm{mM}$ sodium acetate buffer $(\mathrm{pH}$ 5) containing ABTS at a concentration of $2 \mathrm{mM}$ and 50 to $100 \mu \mathrm{l}$ cell free supernatant. The absorbance was measured at $470 \mathrm{~nm}$ using spectrophotometer (JENWAY6705) [13]. One unit of laccase was defined as the amount of the enzyme required to transform 1 mol substrate per min under standard assay conditions.

\subsection{Identification of Isolates}

The isolates were identified based on morphological and biochemical characterization. The identities of the best four isolates on plate screening test were confirmed with 16SrRNA sequencing.

\subsection{DNA Extraction and PCR Amplification}

The bacteria DNA was extracted using Jena Bioscience Kit by following the manufacturer's instructions. The PCR reaction was carried out using the Solis Biodyne $5 \mathrm{X}$ HOT FIREPol Blend Master mix. PCR was performed in $25 \mu \mathrm{l}$ of a reaction mixture, and the reaction concentration was brought down from $5 \mathrm{x}$ concentration to $1 \mathrm{X}$ concentration containing $1 \mathrm{X}$ Blend Master mix buffer (Solis Biodyne), $1.5 \mathrm{mM} \quad \mathrm{MgCl}_{2}, \quad 200 \mu \mathrm{M}$ of each deoxynucleoside triphosphates (dNTP)(Solis Biodyne), 25pMol of each primer (Jena Bioscience, Germany), 2 unit of Hot FIREPol DNA polymerase (Solis Biodyne), Proofreading Enzyme, $5 \mu 1$ of the extracted DNA, and sterile distilled water was used to make up the reaction mixture. Thermal cycling was conducted in an Peltierthermal cycler (PTC100) (MJ Research Series) for an initial denaturation of $95^{\circ} \mathrm{C}$ for 15 minutes followed by 35 amplification cycles of 30 seconds at $95^{\circ} \mathrm{C}$; 1 minute at $60^{\circ} \mathrm{C}$ (Lac; (5'ATGACACTTGAAAAATTTGTGGATGCTCTCCC3' and 5'CTATTTATGGGGATCAGTTATATCCATCGG3'), $\quad 65^{\circ} \mathrm{C}$ (27F; (5'ATGAGTGGCTTGACGCAGGCGCTGCTG3' and 27R (5'CTAGCGCGGGTCCAGCCAGACCAACGATGC 3') and 1 minute 30 Seconds at $72^{\circ} \mathrm{C}$. This was followed by a final extension step of 10 minutes at $72^{\circ} \mathrm{C}$. The amplification product was separated on a $1.5 \%$ agarose gel and electrophoresis was carried out at $80 \mathrm{~V}$ for 1 hour 30 minutes. After electrophoresis, DNA bands were visualized by ethidium bromide staining. 100bp DNA ladder (Solis Biodyne) was used as DNA molecular weight marker.

\subsection{Statistical Analysis}

Data obtained from the study were analyzed using Microsoft Excel 2016. 


\section{Results and Discussion}

In automobile workshops, there is a constant change in the soil microorganism as a result of deliberate spillage of used engine oil. These alter the biomass and ecology of the soil such that both microbial communities and grasses can no longer grow on the soil spots. The colour and texture of the soil are affected; this leads to different microbial flora establishment in an attempt to remedy the petroleum product spillage [14]. Laccase as biocatalysts have received lots of attention because of their high capacity of oxidizing phenolic and other aromatic compounds. These advantages make laccases suitable for bioremediation of polluted sites.

Isolation and screening of hydrocarbon-utilizing bacteria:
Table 1 reports the total bacteria count and total hydrocarbon utilizing bacteria of soil samples from eight automobile workshops. Average count of $7.45 \log _{10} \mathrm{CFU} / \mathrm{ml}$ and 5.44 $\log _{10} \mathrm{CFU} / \mathrm{ml}$ was recorded respectively. However high percentage of hydrocarbon utilizers were recovered from samples in these locations. Prevalence of hydrocarbon degraders in oil polluted environments have been documented in previous researches [15]. The higher count of HUB could also be attributed to long term exposure of these bacteria to hydrocarbons thereby acclimatized to the environment. This agrees with the work of (Rahman et al. [16] who reported that the population levels of hydrocarbon utilizers within the contaminated environment appear to be a sensitive index of environmental exposure to hydrocarbons.

Table 1. Total Bacteria Count ( $\left.\log _{10} C F U / m l\right)$ And Total Hydrocarbon-Degrading Bacteria Count (Log 10 CFU/ml) Of Soil Samples Obtained from Automobile Workshops in Ado-Ekiti.

\begin{tabular}{llll}
\hline SAMPLES & Total bacteria count $\left(\log _{10}\right.$ CFU/ml) & Total hydrocarbon- utilizing bacteria $($ HUB $) \operatorname{count}_{\left(\log _{10} \text { CFU/ml) }\right.}$ \% HUB \\
\hline S1 & $7.08 \pm 0.04$ & $5.31 \pm 0.05$ & 75 \\
S2 & $8.11 \pm 0.02$ & $6.83 \pm 0.01$ & 84 \\
S3 & $6.16 \pm 0.06$ & $4.64 \pm 0.01$ & 75 \\
S4 & $7.28 \pm 0.02$ & $4.85 \pm 0.02$ & 66 \\
S5 & $8.30 \pm 0.05$ & $6.31 \pm 0.01$ & 76 \\
S6 & $7.41 \pm 0.04$ & $5.46 \pm 0.04$ & 73 \\
S7 & $8.37 \pm 0.03$ & $4.64 \pm 0.03$ & 55 \\
S8 & $6.88 \pm 0.04$ & $5.50 \pm 0.05$ & 79 \\
AVERAGE & 7.45 & 5.44 & 73 \\
\hline
\end{tabular}

Laccase enzyme screening:

Twenty-nine hydrocarbon degraders recovered from the mechanic workshop soil samples showed different reactions on the tannic acid agar. Oxidation of tannic acid was evident by development of black coloration (Figure 1). Four isolates (MW 4, MW 5, MW 8 \& MW 11) showed oxidation of tannic-acid within 24h, three isolates (MW 2, MW 15, \& MW 21) oxidized tannic acid after $72 \mathrm{~h}$ and the remaining isolates did not show any coloration. It was observed that incubation period required for proper growth and development of colored precipitate varied with individual organism.

The seven isolates that gave a positive reaction on tannicacid agar were subjected to further quantitative laccase screening.

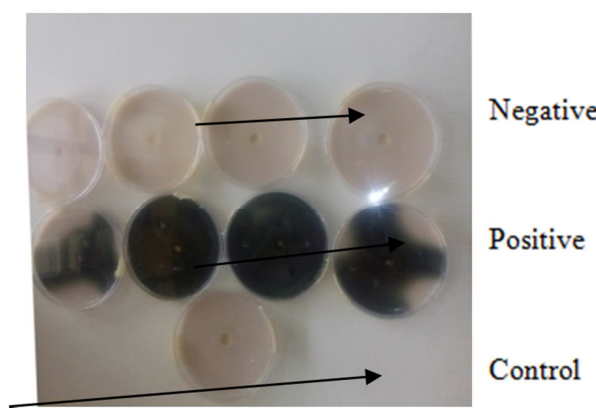

Figure 1. Sample plate showing laccase screening on tannic acid agar plate.

Quantitative Assay of Laccase

Laccase activity was determined using ABTS [2, 2azino-bis (3-ethylbenzthiazoline-6-sulfonic acid)] as a substrate over a period of $96 \mathrm{~h}$. All the seven isolates that gave positive reaction on the tannic-acid agar were subjected to quantitative screening. Laccase activity increased gradually with time to attain the optimum between 48 and $72 \mathrm{~h}$ and later declined after $96 \mathrm{~h}$ as shown in Figure 2. Incidentally, isolates MW15 and MW21 which gave late positive reaction (after $72 \mathrm{~h}$ ) on plate screening had the highest laccase activity of $3.43 \mathrm{U} / \mathrm{ml}$ and $3.09 \mathrm{U} / \mathrm{ml}$ respectively after $72 \mathrm{~h}$ while their counterparts MW5 and MW11 which gave fast positive reaction on tannic-agar plate had considerably lower activity of $1.56 \mathrm{U} / \mathrm{ml}$ and 1.15 $\mathrm{U} / \mathrm{ml}$ respectively. However, it has been reported that plate assay test for screening based on colour indicator compounds viz. guaiacol and tannic acid are efficient substrates to obtain novel laccase producers [17] but some of the microbes that showed rapid positive reactions on tannic-acid produced low laccase in liquid cultures. This shows that quantification assay is more sensitive that the plate screening method.

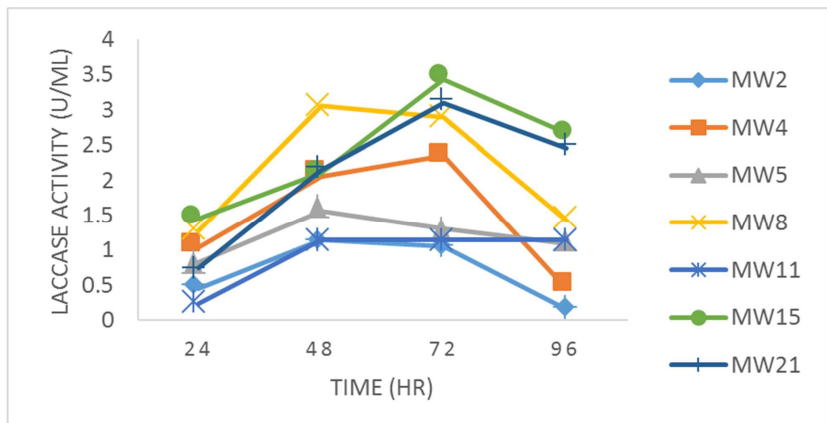

Figure 2. Qualitative assay of Laccase in hydrocarbon-degrading bacteria.

Identification of the isolates: The four isolates with the 
highest laccase activity were identified as Lactobacillus sakei, Pseudomonas aeruginosa, Bacillus cereus and Gracilibacter thermotolerans based on 16SrRNA sequencing.

Sample A- Lactobacillus sakei strain DSM 20017 16S ribosomal RNA gene, partial sequence
Sequence ID: gi|343201717|NR_042443.1Length: 1561Number of Matches: 1

Related Information

Range 1: 257 to 291GenBankGraphics Next Match Previous Match

Table 2. \% Sequence similarities of Isolate M4 with closest relatives from the Genbank database.

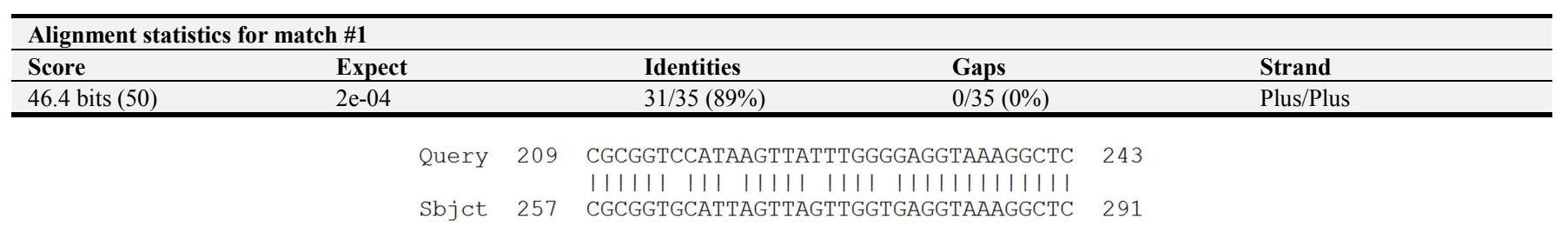

Sample B-Pseudomonas aeruginosa strain DSM 50071 16S ribosomal RNA, complete sequence

Sequence ID: gi|219846486|NR_026078.1Length: 1537Number of Matches: 1

Related Information

Range 1: 10 to 934GenBankGraphics Next Match Previous Match

Table 3. \% Sequence similarities of Isolate M8 with closest relatives from the Genbank database.

\begin{tabular}{|c|c|c|c|c|}
\hline \multicolumn{5}{|c|}{ Alignment statistics for match \#1 } \\
\hline Score & \multicolumn{2}{|c|}{ Expect } & Identities & Strand \\
\hline \multirow[t]{8}{*}{1548 bits (1716) } & 0.0 & & $906 / 929(98 \%)$ & Plus/Plus \\
\hline & Query & 1 & 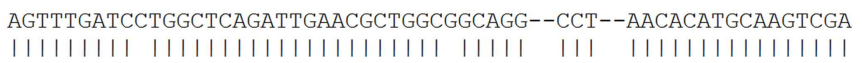 & 56 \\
\hline & Sbjet & 10 & AGTTTGATCATGGCTCAGATTGAACGCTGGCAGCAGGGGCCTTCAACACATGCAAGTCGA & 69 \\
\hline & Query & 57 & 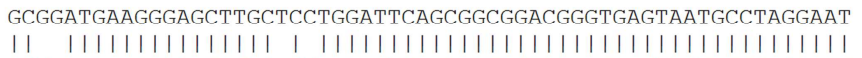 & 116 \\
\hline & Sbjet & 70 & GCTTATGAAGGGAGCTTGC-CTTGGATTCAGCGGCGGACGGGTGAGTAATGCCTAGGAAT & 128 \\
\hline & Query & 117 & 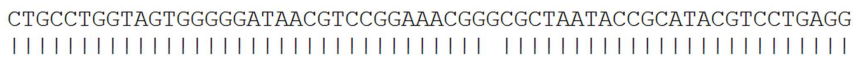 & 176 \\
\hline & Sbjet & 129 & CTGCCTGGTAGTGGGGGATAACGTCCGGAAACGGCCGCTAATACCGCATACGTCCTGAGG & 188 \\
\hline & Query & 177 & 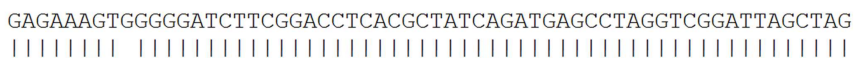 & 236 \\
\hline
\end{tabular}

Sample C -Bacillus cereus ATCC 14579 16S ribosomal RNA (rrnA) gene, complete sequence

Sequence ID: gi|444304116|NR_074540.1Length: 1512Number of Matches: 2

Related Information

Range 1: 134 to 629GenBankGraphics Next Match Previous Match

Table 4. \% Sequence similarities of Isolate M21 with closest relatives from the Genbank database.

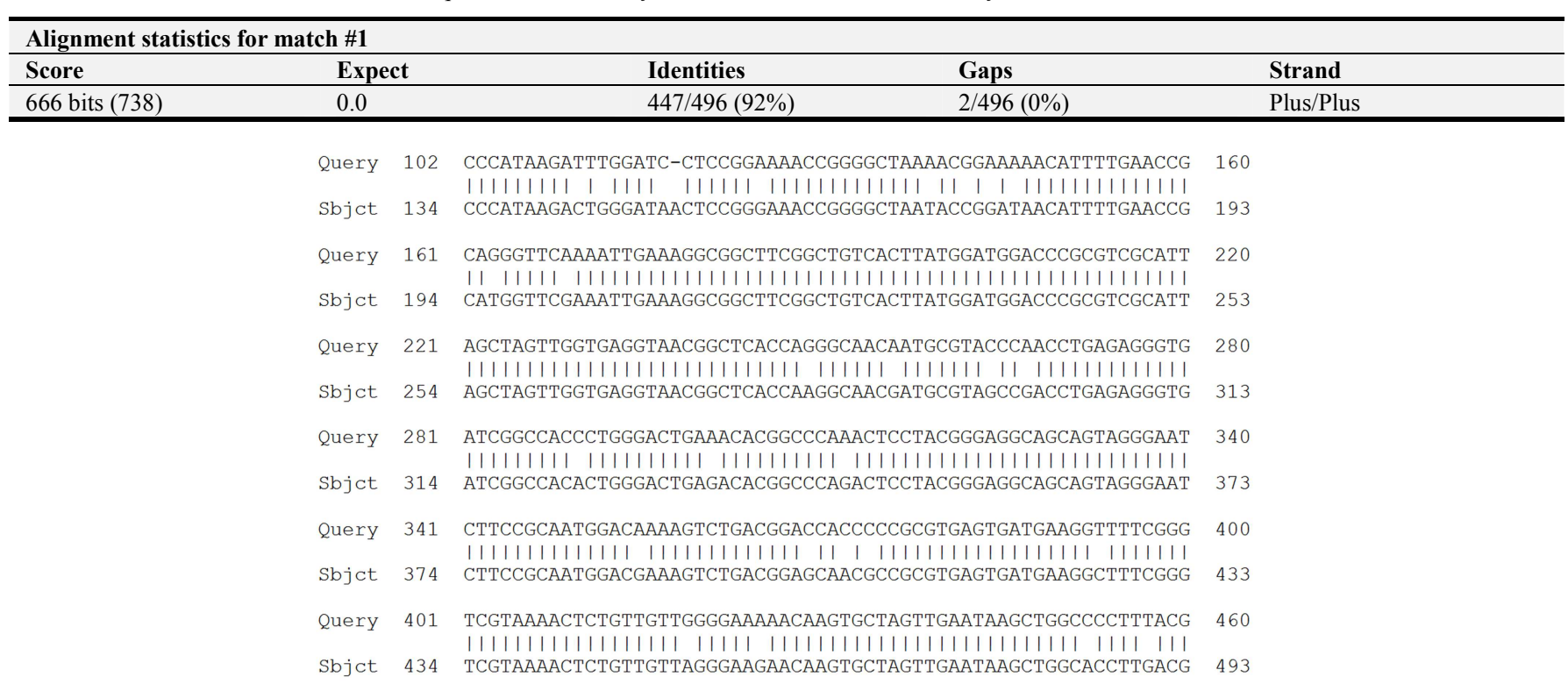




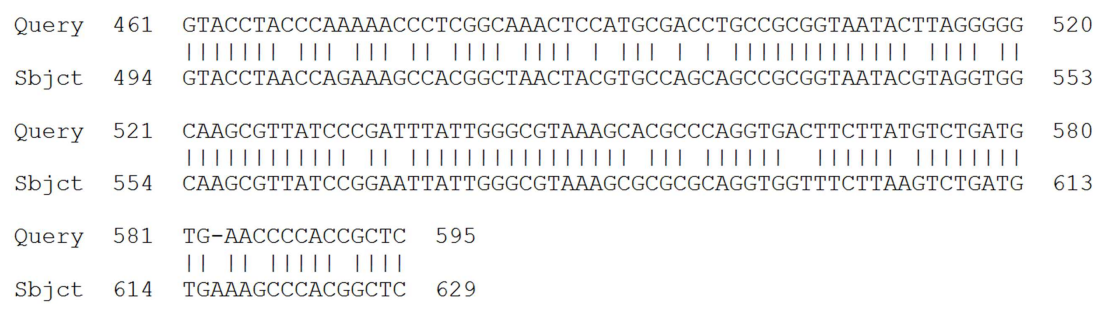

Sample D-Gracilibacter thermotolerans strain JW/YJL-S1 16S ribosomal RNA gene, partial sequence Sequence ID: gi|636559633|NR_115693.1Length: 1526Number of Matches: 1

Related Information

Range 1: 1383 to 1416 GenBankGraphics Next Match Previous Match

Table 5. \% Sequence similarities of Isolate M15 with closest relatives from the Genbank database.

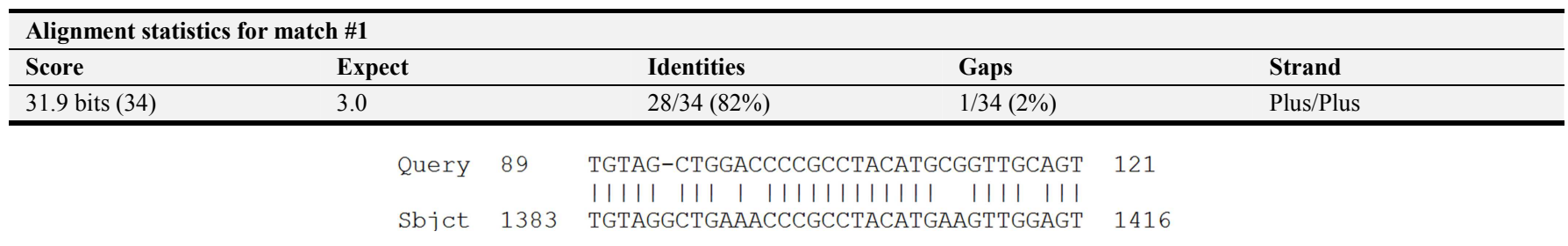

PCR amplification: PCR amplification of laccase producing bacteria using DNA specific primer (Primerpair 27R (5'ATGAGTGGCTTGACGCAGGCGCTGCTG3') and 27R (5'CTAGCGCGGGTCCAGCCAGACCAACGATGC3').

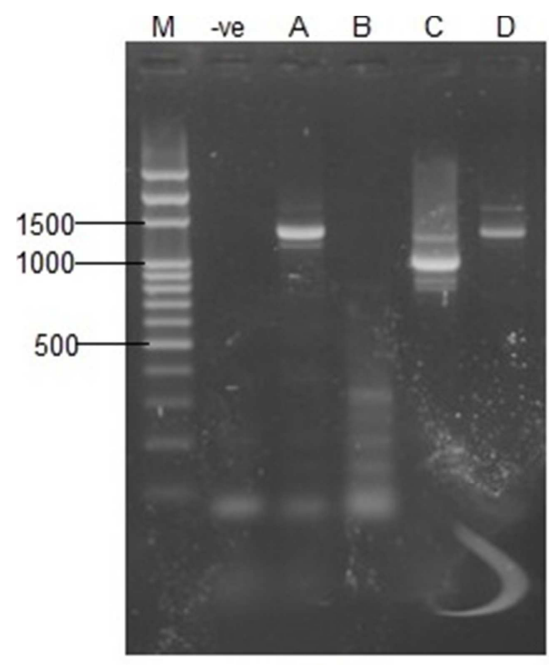

27F@65

Figure 3. Amplication of Laccase primer by the selected hydrocarbon-degrading bacteria.

Key: M: 100 bp DNA ladder, Invitrogen (positive control), -ve: negative control line. Lane A=Lactobacillus sakei, Lane B=Pseudomonas aeruginosa, Lane $\mathrm{C}=$ Bacillus cereus $\&$ Lane $\mathrm{D}=$ Gracilibacter thermotolerans.

\section{Conclusion}

The study revealed that hydrocarbon degraders from oil contaminated sites have laccase-producing abilities. The findings also revealed that plate screening can present a false representation of laccase-producing abilities of isolates. Hence, quantitative assay and amplification of primers specific for laccase is necessary for the confirmation of plate screening results. The laccase from the isolated strains can enhance their efficiency in bioremediation of industrial effluents and oil contaminated environments.

\section{References}

[1] Cerniglia, N. and Sutherland, M. (2001). Application Environmental Microbiology. 63: 4120-4122.

[2] Clemente, A., Dimcheva, N., Ferapontova, E. E., Gorton, L., Ruzgas, T., Stoica, L., Shleev, S., Yaropolov, A. I., Haltrich, D., Thorneley, R. N. and Austin, S. D. (2001). Application of Microbiology and Biotechnology. 16: 1074-1092.

[3] Bird, C. E. Cavanaugh, E. G. Dickerman, J. C. and Fernandes, S. R. (2008). A Study of Vapor Control Methods for Gasoline Marketing Operations. U.S. Environmental Protection Agency. 171: 31-36. 
[4] Zouari-Mechichi, H., Mechichi, T., Dhouib, A., Sayadi, S., Martinez, A. T, mMartinez, M. J., (2005). Laccase purification and characterization from Trametes trogii isolated in Tunisia: decolorization of textile dyes by the purified enzyme. Enzyme Microbial Tech., 39: 141-148.

[5] Desai, S., Nityanand, C. (2011). Microbial laccases and their applications: a review. Asian J Biotechnol, 3 (2): 98-124.

[6] Bains J, Capalash N, Sharma P (2003). Laccase from a nonmelanogenic, alkalotolerantc-proteobacterium JB isolated from industrial wastewater drained soil. Biotechnol Lett 25 (1) 155-1159.

[7] Michael, M. T., M. G. Georg and R. Astrid (2005). Degradation of Azo dyes by lacase and ultrasound treatment. Apl. Environ. Microbiol. 71: 260-2607.

[8] Elsayed, M. A., Hassan, M. M., Elshafei, A. M., Haroun, B. M Ot man, A. M. (2012). Optimization of cultural and nutritional parameters for the production of laccase by Pleurotus ostreatus ARC280. British Biotechnology Journal, 2 (3), 115132.

[9] Baldrian, P. (2006). "Fungal laccases-occurrence and properties,"FEMS Microbiology Reviews, vol. 30, no. 2, pp. 215-242.

[10] Sivakumar R, Rajendran R, Balakumar C, Tamilvendan M (2010). Isolation, screening and optimization of production medium for thermostable laccase production from Ganoderma sp. Int. J. Eng. Sci. Technol. 2 (12): 7133-7141.
[11] Pointing, S. B. (1999). Qualitative methods for the determination of lignocellulolytic enzyme production by tropical fungi. Fungal Diversity 2, 17-33.

[12] Bourbonnais, R., Leech, D. and Paice, M. G. (1998). "Electrochemical analysis of the interactions of laccase mediators with lignin model compounds," Biochimica et Biophysica Acta, vol. 1379, no. 3, pp. 381-390.

[13] Majcherczyk, A., Johannes, C. and A. Huttermann, A. (1998). "Oxidation "of polycyclic aromatic hydrocarbons (PAH) by laccase of Trametes versicolor," Enzyme and Microbial Technology, vol. 22, no. 5, pp. 335-341.

[14] Barathi, S. and Vasudevan, N. (2001). Utilization of petroleum hydrocarbons by pseudomonas flourescens isolated from petroleum contaminated soil. Environmental International. 26: 413-416.

[15] Olowomofe T. O, Oluyege J. O, Sowole D. O (2017). Isolation, screening and characterization of hydrocarbon-utilizing bacteria isolated from bitumen-contaminated surface water in Agbabu, Ondo State. J Adv Biol Biotechnol 15: 1-9.

[16] Kiiskinen, L. L., Rättö, M., Kruus, K. (2004). Screening for novel laccase-producing microbes. Journal of applied microbiology, 97 (3): 640-646.

[17] Rahman KSM, Rahman TJ, Kourkoutas Y, Petsas I, Marchant R, Banat I. M. (2003). Enhanced bioremediation of N-alkane in petroleum sludge using bacterial consortium amended with rhamnolipid and micronutrients. Biores. Technol., 90: 159-168. 